\title{
1. Controlling EU agencies: an introduction
}

\section{Miroslava Scholten, Béla Strauss and Alex Brenninkmeijer}

\section{EVOLUTION OF THE EXECUTIVE BRANCH AND CHALLENGES TO CONTROLS}

Agencification and Europeanisation have become the major trends affecting the exercise of executive powers in the EU in recent years. This in turn raises the question of how effective control over the exercise of executive power in the EU can be ensured, ${ }^{1}$ and arbitrary interferences with rights and freedoms of private actors prevented. This book addresses this question following the idea that complex governance structures like the EU require the establishment of sophisticated controlling systems, which can be achieved by connecting relevant concepts, types and systems (both EU and national) of control. ${ }^{2}$ It is the first publication to offer a collection of chapters by renowned academics and practitioners on individual relevant concepts of control and EU agencies representing all the various functional groups, as well as a discussion about the useful connections for building the complex system of controls in the EU multi-jurisdictional legal order essential to ensure the rule of law. With this volume, we hope to advance the debate on the controls over EU agencies and the EU executive by offering novel insights about a 'systemic level' of the system of controls and making more specific connections between concrete outputs by agencies and specific types of controls.

In 2020 , EU agencies will be celebrating the 45 th anniversary of the creation of the first two EU agencies in 1975. Agencies are certainly not a modern

1 See D Curtin, 'Challenging Executive Dominance in European Democracy', [2014] 77(1) Modern Law Review, 1-32.

2 M Scholten, 'Shared Tasks, but Separated Controls: Building the System of Control for Shared Administration in an EU Multi-Jurisdictional Setting', [2019] European Journal of Risk Regulation, early view: DOI: https://doi.org/10.1017/err .2019.33 (last checked September 2019). 
invention. ${ }^{3}$ The increase in the number and variety of agencies, in particular within the EU legal order however, features a new type of 'agencification', ${ }^{4}$ also because it promotes another phenomenon - Europeanisation of the executive power - leading to the proliferation of EU shared administration. Despite the fact that there are certain political and legal-constitutional limitations to these processes ${ }^{5}$ the system of EU governance is growing increasingly complex and EU agencies with various powers - from information-gathering to regulatory and direct enforcement - play an increasingly important role here. ${ }^{6}$ Indeed, conceiving of a functioning Union without agencies is close to impossible, ${ }^{7}$ and some authors speak of an extensive 'Eurocracy' outside of the Commission, of which agencies form an integral part. ${ }^{8}$ This is particularly serious because agencies lack a formal legal basis in the treaties and yet are often granted a significant degree of independence precisely to ensure that they can effectively fulfil the tasks entrusted to them, and because they frequently

\footnotetext{
3 P Craig, EU Administrative Law (Oxford University Press 2016), 141.

4 M Scholten and M Van Rijsbergen, 'The Limits of Agencification in the European Union', [2014] 7 German Law Journal, 1223-1256; M Chamon, 'Agencification in the United States and Germany and What the EU Might Learn From It', [2016] 17(2) German Law Journal, 119-152; H C H Hofmann and A Morini, 'Constitutional Aspects of the Pluralisation of the EU Executive through "Agencification"”, [2012] 37 European Law Review 419.

5 In particular the Meroni doctrine and institutional balance. See for a more detailed and comprehensive analysis of these limitations, Craig (n 3); M Chamon, EU Agencies: Legal and Political Limits to the Transformation of the EU Administration (Oxford University Press 2016); M Chamon, 'Granting Powers to EU Decentralised Agencies, Three Years following Short-Selling', [2018] 18(4) ERA Forum, 597-609; M Scholten and M Van Rijsbergen, 'The ESMA-short Selling Case: Erecting a New Delegation Doctrine in the EU upon the Meroni-Romano Remnants', [2014] 41(4) Legal Issues of European Integration, 389-405. See also M Simoncini, 'Legal Boundaries of European Supervisory Authorities in the Financial Markets: Tensions in the Development of True Regulatory Agencies', [2015] 34(1) Yearbook of European Law, 319-350.

$6 \quad$ D Geradin, R Munoz and N Petit, Regulation Through Agencies in the EU: A New Paradigm of European Governance (Edward Elgar Publishing 2005); E Chiti, 'European Agencies' Rulemaking: Powers, Procedures and Assessment', [2013] 19(1) European Law Journal, 93-110; H C H Hofmann, 'European Regulatory Union? The Role of Agencies and Standards', in P Koutrakos and J Snell (eds.), Research Handbook on the EU's Internal Market (Edward Elgar Publishing 2017), 460-479.

7 M Everson and E Vos, 'European Agencies: What About Institutional Balance?', in A Lazowski and S Blockmans (eds.), Research Handbook on EU Institutional Law (Edward Elgar Publishing 2016), 139-151.

8 R D Kelemen and A D Tarrant, 'The Political Foundations of the Eurocracy', [2011] 34(5) West European Politics, 922-947.
} 
operate in technical fields, making a review by classic controlling, non-expert forums difficult. ${ }^{9}$

Over 35 EU agencies exist today with various functions, which may be classified in many different ways, including information-gathering, cooperation-providing and service-providing, advisory, decision-making and enforcement. ${ }^{10}$ These agencies execute various tasks and take a variety of decisions such as issuing certificates, permits, fines or guidance documents. Moreover, no one particular formula exists as to how similar types of decisions may be taken. While the (non-binding) 'Common Approach'" ${ }^{11}$ on EU agencies has been an attempt to streamline some aspects of the establishing and functioning of agencies, it has neither set up a specific list of functions, powers and related procedures and acts that agencies can deal with, nor has it established a comprehensive system of controls over the agencies and their specific outputs. There is therefore still a pressing need for a structured, coherent and consistent system of control ${ }^{12}$ that at the same time does not compromise the

$9 \quad$ In the context of the EU, the CJEU has described the EU as a union based on the rule of law, meaning that institutions cannot avoid and are subject to review of the compatibility of their acts with the basic treaties, general principles of law and fundamental rights. See Case 294/83 Parti écologiste 'les verts' v European Parliament EU:C: 1986:166, point 23; Case C-583/11 P Inuit Tapiriit Kanatami and others $v$ European Parliament and Council of the European Union. EU:C:2013:625, point 91. The Commission's view on the rule of law is also interesting and relevant, giving a more substantive interpretation of the concept than a purely formal or procedural definition of the concept, which would only require 'that any action of a public official be authorized by law'; instead, '[t]he Commission considered that the notion of the Rule of Law requires a system of certain and foreseeable law, where everyone has the right to be treated by all decision-makers with dignity, equality and rationality and in accordance with the laws, and to have the opportunity to challenge decisions before independent and impartial courts through fair procedures.' See the Venice Commission's Rule of Law Checklist, 6 https://www.venice.coe.int/webforms/documents/default .aspx?pdffile=CDL-AD(2016)007-e accessed 1 May 2019. See also article 2 Treaty on European Union (TEU).

10 The number, function and types of agencies may vary. See for other typologies and classifications Craig (n 3); E Chiti, 'Decentralisation and Integration into the Community Administrations: A New Perspective on European Agencies', [2004] 10(4) European Law Journal, 402-438; M Scholten, The Political Accountability of EU Agencies: Learning from the US Experience (Brill Nijhoff 2014); H C H Hofmann, G C Rowe and A H Türk, Administrative Law and Policy of the European Union (Oxford University Press 2011); Ellen Vos, EU Agencies, Common Approach and Parliamentary Scrutiny (European Parliamentary Research Service 2018).

11 See the 2012 Joint Statement of the European Parliament, the Council of the EU and the European Commission on decentralised agencies, as well as the 2012 Common Approach annex thereto.

12 European Parliamentary Research Service, EU Agencies, Common Approach and Parliamentary Scrutiny (2018). 
independence of agencies and, by extension, the effective use of their technical expertise and competence.

As the mandates of agencies become more complex and the competences grow, a control and rule of law perspective on the role of agencies within procedures resulting in the exercise of executive power becomes ever more important. There may be accountability gaps or dilemmas. ${ }^{13}$ Evidence suggests that simply introducing more rules to improve trust and integrity is ineffective: ${ }^{14}$ complex problems may require sophisticated solutions and controlling systems. 'The sophistication comes at least from two perspectives: connecting various types of controls - political accountability mechanisms, judicial review, financial audits and others - and aligning the systems of controls belonging to different jurisdictions (EU-national, national-national) for the exercise of (shared) tasks by executive actors belonging to those different jurisdictions. ${ }^{15}$ It is thus essential to connect relevant concepts, types and jurisdictions of control to build a much-needed comprehensive and effective system of controls. This volume makes a start by bringing relevant concepts of controls together in order to discuss possible connections and beneficial interplays between those concepts and types of controls they represent, so as to promote the building of a comprehensive system of controls. It does so at the conceptual level in Part I and in relation to specific agencies' tasks and outputs in Part II.

\section{KEY CONCEPTS OF CONTROL}

The question of how an effective and appropriate level of control over EU institutions can be achieved has been studied by scholars from different disciplines

13 M Bovens, D Curtin, and P 't Hart, 'The EU's Accountability Deficit: Reality or Myth?', in M Bovens, D Curtin and P 't Hart (eds.), The Real World of EU Accountability: What Deficit? (Oxford University Press 2010); M Scholten, M Maggetti and E Versluis, 'Political and Judicial Accountability in Shared Enforcement in the EU', in M Scholten and M Luchtman (eds.), Law Enforcement by EU Authorities (Edward Elgar Publishing 2017), 353-375; P Leino, 'Accountability Dilemmas of Regulating Financial Markets Through the European Supervisory Agencies', in C Harlow, P Leino and G della Cananea (eds.), Research Handbook on EU Administrative Law (Edward Elgar Publishing 2017); see also D Curtin and A Nollkaemper, 'Conceptualizing Accountability in International and European Law', [2005] 36(1) Netherlands Yearbook of International Law, 6.

14 See A Brenninkmeijer, S Mazur, T Randma-Liiv and M St. Aubyn, 'Reflections on Performance, Integrity and Trust in the Public Sector in Europe', http://www.eupan .eu/files/repository/20160202140628_2016-01-21_-_Essays_European_Experts_final .pdf accessed 1 May 2019.

15 Scholten (2019) (n 2). 
- such as legal and political science - in which different concepts and literature streams have been developed, but they have not yet been comprehensively brought together. ${ }^{16}$ These concepts include, amongst others, accountability, liability, protection of fundamental rights, the principle of judicial protection and transparency. We can classify these concepts as ways to ensure effective control over the executive branch to promote the rule of law. The concepts of judicial deference and independence also need to be considered as they influence the 'quantity and quality' of controlling mechanisms so that both the ideal of the rule of law and the need for effective operation of the executive can be maintained. Below, we give a brief outline of our understanding of these concepts, how we define them, and how they can be contextualised in relation to one another and with respect to EU agencies. While we do not claim that the list is exhaustive, we hope that this first attempt at bringing relevant concepts together could inspire future research in making connections with other concepts as well.

As Europeanisation is a concept that can affect the way in which the identified concepts operate, we consider it necessary to first discuss this concept. In particular, Europeanisation may affect other concepts in terms of:

(i) their locus (where is control ensured over a certain exercise of executive power, at the national or EU level, both or neither?);

(ii) their effectiveness (for example, can a national court effectively review a certain decision based on an EU agency action?);

(iii) their appropriateness (should a national court be able to conduct such a review? Are there perhaps other, more suitable ways to ensure accountability and control?).

We understand Europeanisation as the emergence of a multi-jurisdictional, composite legal order where EU national legal systems interact with the EU (vertically) and amongst themselves (horizontally). This complex multi-jurisdictional structure affects the manner in which executive power across levels and jurisdictions can effectively be controlled, in particular in a polity with a large variety of legal standards and safeguards. In our view, in order for such control to be effective, a sophisticated system of controls must be put in place, in which different types of controls and different levels or jurisdictions of control are aligned with one another, and with the type of power exercised. ${ }^{17}$

\section{Ibid.}

17 See for an analysis of the EU's integrated administration, $\mathrm{H} \mathrm{C} \mathrm{H} \mathrm{Hofmann}$ and A Türk, 'The Development of Integrated Administration in the EU and its Consequences', [2007] 13(2) European Law Journal, 253-271. 
Independence or autonomy ${ }^{18}$ is an important concept in the control and accountability debate because, depending on the degree of independence which an agency has been accorded to fulfil a certain task, the availability and appropriateness of various mechanisms of control may also differ in light of that task. ${ }^{19}$ It should be noted that formal autonomy does not necessarily coincide with de facto autonomy, and agencies may not necessarily behave in line with their formal positions, which is a theme that is seen to resurface repeatedly in the case studies. ${ }^{20}$ Some agencies may use and perceive greater autonomy than is officially accorded to them, while the reverse is also possible. ${ }^{21}$ There is an important connection between autonomy and control: control refers to a range of mechanisms employed by the controlling actor in order to direct, steer and influence the decision-making and behaviour of the controlled agents. Complete control is thus incompatible with complete independence. ${ }^{22}$ Independence and accountability, however, are not incompatible because accountability does not imply a direct steering of the agent, but rather an ex post evaluation. ${ }^{23}$ Control may therefore be divided into three dimensions: $e x$ ante, ongoing, and ex post (or accountability). ${ }^{24}$

Following Bovens, we can define accountability as 'a relationship between an actor and a forum, in which the actor has an obligation to explain and to justify his or her conduct, the forum can pose questions and pass judgment,

18 The debate about the different connotations which these two terms may have has not been included in this volume.

19 A Wonka and B Rittberger, 'Credibility, Complexity and Uncertainty: Explaining the Institutional Independence of 29 Agencies', [2010] 33(4) West European Politics, 730-752; see Chapter 3 on the discussion of these concepts.

20 B Kleizen, K Verhoest, and J Wynen, 'Structural Reform Histories and Perceptions of Organizational Autonomy: Do Senior Managers Perceive Less Strategic Policy Autonomy When Faced with Frequent and Intense Restructuring?', [2018] 96(2) Public Administration, 349-367; M Shapiro, 'The Problems of Independent Agencies in the United States and the European Union', [1997] 4(2) Journal of European Public Policy, 276-291.

21 D P Carpenter, 'Adaptive Signal Processing, Hierarchy, and Budgetary Control in Federal Regulation', [1996] 90(2) American Political Science Review, 283-302.

22 M Maggetti, K Ingold and F Varone, 'Having Your Cake and Eating It, Too: Can Regulatory Agencies Be Both Independent and Accountable?', [2013] 19(1) Swiss Political Science Review, 1-25.

${ }_{23}$ Ibid; G Majone, 'The Regulatory State and Its Legitimacy Problems', [1999] 22(1) West European Politics, 1-24; D Geradin and N Petit, 'The Development of Agencies at EU and National Levels: Conceptual Analysis and Proposals for Reform', [2004] 23 Yearbook of European Law, 137-197.

${ }^{24}$ Ibid. See also M Busuioc, 'Accountability, Control and Independence: The Case of European Agencies’, [2009] 15(5) European Law Journal, 599-615. 
and the actor may face consequences' ${ }^{25}$ this definition has been followed in many landmark studies on accountability in the EU. ${ }^{26}$ It is the corollary to (public) power. Thus, accountability is necessary in those situations in which direct control has been relinquished and the agent has become (relatively) autonomous (to allow it to achieve certain goals more effectively), as is often the case for agencies.

A necessary precondition to accountability is a certain degree of transparency and quality of information, otherwise the accountability forum will not know which questions to ask or how to judge. ${ }^{27}$ As has been pointed out by Buijze, ${ }^{28}$ 'a transparent government is one that provides people with the information they need to ascertain and understand the state of the world and to predict how their own actions will affect that world, and that does not unnecessarily complicate that world' ${ }^{29}$ The same can be said to apply to agencies, where forums must understand the state of the agency world if they are to hold agencies accountable.

It should be noted that more accountability or transparency is not necessarily a good thing, and that too much accountability may produce risks of its own. ${ }^{30}$

25 M Bovens, 'Analysing and Assessing Accountability: A Conceptual Framework', [2007] 13(4) European Law Journal, 447-468.

26 M Maggetti, G J Brandsma, E Heidbreder and E Mastenbroek, 'Accountability in the Post-Lisbon European Union', [2017] 82(4) International Review of Administrative Sciences, 621-637; G J Brandsma and J Adriaensen, 'The Principal-Agent Model, Accountability and Democratic Legitimacy', in T Delreux and J Adriaensen (eds.), The Principal Agent Model and the European Union (Palgrave Macmillan 2017); G J Brandsma and T Schillemans, 'The Accountability Cube: Measuring Accountability', [2012] 23(4) Journal of Public Administration Research and Theory, 953-957; C Moser, EU Civilian Crisis Management - Law and Practice of Accountability (Utrecht University 2018); M Busuioc, The Accountability of EU Agencies: Legal Provisions and Ongoing Practices (Eburon 2010); A Karagianni and M Scholten, 'Accountability Gaps in the Single Supervisory Mechanism (SSM) Framework', [2018] 34(2) Utrecht Journal of International and European Law, 185-194.

27 G J Brandsma, D Curtin and A Meijer, "How Transparent are EU "Comitology" Committees in Practice?', [2008] 14(6) European Law Journal, 819-838; Y Papadopoulos, 'Accountability and Multi-Level Governance: More Accountability, Less Democracy?', [2010] 33(5) West European Politics, 1030-1049.

28 A Buijze, The Principle of Transparency in EU Law (BOXpress 2013), 31.

29 Transparency has also been understood differently, not as a quality but as a measure. In this sense, transparency is 'a measure of the degree to which information about official activity is made available to an interested party'. See W B T Mock, 'On the Centrality of Information Law: A Rational Choice Discussion of Information Law and Transparency', [1999] 17 John Marshall Journal of Computer \& Information Law, 1082.

30 M Bovens, 'Public Accountability', in E Ferlie, L E Lynne Jr and C Pollitt (eds.), The Oxford Handbook of Public Management (Oxford University Press 2005), 
Transparency may, for instance, need to be balanced with confidentiality and privacy requirements. In this light, our idea of connecting different concepts and other relevant rights and notions seems even more relevant as it aims to address the questions concerning the finding of an optimal mix between such, at times, contradictory needs.

While various types of accountability may be distinguished, for example political, judicial and professional, ${ }^{31}$ studying some of these types of accountability, like legal accountability by courts, brings us to publications of different disciplines. ${ }^{32}$ In order for legal accountability to be effective, the principle of effective judicial protection, ${ }^{33}$ protection of fundamental rights and liability seem essential. ${ }^{34}$ The rule of law requires that no institution of the EU, including agencies, can avoid a review of the question whether an adopted measure is in conformity with EU law. ${ }^{35}$ The previously mentioned principle of effective judicial protection may even 'imply that a preparatory act which would not normally be open to appeal according to national law may nevertheless be regarded as a decision against which appeal is possible', ${ }^{36}$ which can be of considerable importance for agencies with less formal powers. Fundamental rights can serve as an important check on agencies' operations in some policy areas where fundamental rights violations and violations of the legally binding Charter of Fundamental Rights are perhaps more likely to occur. ${ }^{37}$ In a similar

182-208; C Hood, 'What Happens when Transparency Meets Blame-Avoidance?', [2007] 9(2) Public Management Review, 191-210; D Heald, 'Transparency as an Instrumental Value', in C Hood and D Heald (eds.), Transparency: The Key to Better Governance? (Oxford University Press 2006), 59-73; M Philp, 'Delimiting Democratic Accountability', [2009] 57 Political Studies, 28-53.

31 Bovens (2007) (n 25).

32 M Scholten, M Luchtman and E Schmidt, 'The Proliferation of EU Enforcement Authorities: A New Development in Law Enforcement in the EU', in M Scholten and M Luchtman (eds.), Law Enforcement by EU Authorities (Edward Elgar Publishing 2017), 1-27.

33 Case C-64/16 Associação Sindical dos Juizes Portugueses EU:C:2018:117; more broadly, see M Eliantonio, 'Judicial Control of the EU Harmonized Standards: Entering a Black Hole?', [2017] 44(4) Legal Issues of Economic Integration, 395-407.

34 See A Prechal, 'The Court of Justice and Effective Judicial Protection: What Has the Charter Changed?', in C Paulussen, T Takacs, V Lazic and B Van Rompuy (eds.), Fundamental Rights in International and European Law (TMC Asser Press 2015), 143-157; M Eliantonio, 'Information Exchange in European Administrative Law: A Threat to Effective Judicial Protection', [2016] 23(3) Maastricht Journal of European and Comparative Law, 531-549.

35 Case 294/83, Parti écologiste 'les verts' v European Parliament EU:C:1986:166.

36 Ibid. See also Case C-97/91 Borelli EU:C:1992:491.

37 L Marin, 'Policing the EU's External Borders: A Challenge for the Rule of Law and Fundamental Rights in the Area of Freedom, Security and Justice? An Analysis of Frontex Joint Operations at the Southern Maritime Border', [2011] 7(4) 
vein to fundamental rights, liability of EU agencies offers another rights-based claim that can be made before a (national) court and thus ensure scrutiny for an agency action. While formally concerning a procedure purely between parties, tort law and liability can nevertheless have a more general impact and transcend the original procedure, affecting both litigants and non-litigants. ${ }^{38}$

Judicial review $^{39}$ (or legal accountability, which is the term used by public administration scholars) cannot be fully understood without considering the concept of judicial deference. Deference affects the 'content' of judicial review as a controlling mechanism. A review can be very marginal, in which case the court limits itself to examining whether or not a decision is clearly unreasonable. ${ }^{40}$ The review is, in that case, not very thorough, as opposed to a full review in which case the court will examine all aspects of the decision, both factual and legal, and make a decision de novo. ${ }^{41}$ The intensity of judicial review can then be seen as a point on a sliding scale between a very marginal and a full review. Deference relies on the assumption that all procedures governing decision-making and regulation are working correctly, that these are transparent and that the authority has more expertise than the court when it comes to the specific case (which, in the case of agencies, is essentially a given). ${ }^{42}$ In practice, especially in the context of technical policy fields in which agencies often operate, some of these assumptions may be unrealistic and judicial deference may be seen as a challenge to effective control over agencies' discretion or even a source of a lack of such control.

Journal of Contemporary European Research, 468-489. In that context, see also D Fernandez-Rojo, 'The Introduction of an Individual Complaint Mechanism within FRONTEX: Two Steps Forward, One Step Back', [2016] 71(4-5) Tijdschrift voor bestuurswetenschappen en publiek recht, 226-235. On the Charter and judicial protection, see Prechal (n 34).

38 E R De Jong, M G Faure, I Giesen and P Mascini, 'Judge-Made Risk Regulation and Tort Law: An Introduction', [2018] 9(1) European Journal of Risk Regulation, 6-13; E R De Jong, 'Tort Law and Judicial Risk Regulation: Bipolar and Multipolar Risk Reasoning in Light of Tort Law's Regulatory Effects', [2018] 9(1) European Journal of Risk Regulation, 14-33.

39 R Widdershoven, 'The European Court of Justice and the Standard of Judicial Review', in J De Poorter, E Hirsch Ballin and S Lavrijssen (eds.), Judicial Review of Administrative Discretion in the Administrative State (TMC Asser Press 2019).

40 S Lavrijssen and M De Visser, 'Independent Administrative Authorities and the Standard of Judicial Review', [2006] 2 Utrecht Law Review, 111-135. See also Craig (n 3).

${ }^{41}$ M Bernatt, 'The Compatibility of Deferential Standard of Judicial Review in the EU Competition Proceedings with Article 6 of the European Convention on Human Rights', [2014] Institute for Consumer Antitrust Studies Working Papers, 2.

42 Ibid. 
While the list of relevant concepts taken on board in this book may not be exhaustive, this volume offers a start to exploring an idea of looking for possible useful connections in order to build a comprehensive system of controls. To what extent can political accountability address the challenges of judicial review which is limited by the deferential treatment by courts of technical assessments of agencies? To what extent could the ex ante procedural safeguards (participation, consultation, notification) attached to making a soft law guideline compensate for a limited judicial check of a legally non-binding act? ${ }^{43}$ Could relevant internal controlling mechanisms (and which ones?) compensate for the possibly limited external control of agencies' confidential files? We invite scholars and practitioners to explore even further these and other relevant questions in light of connecting relevant concepts and types of controls, by also linking additional concepts and types of controls, theoretical and empirical insights and literature streams from different disciplines.

\section{METHODOLOGICAL CONSIDERATIONS}

This volume's underlying question concerns how agency independence and competence (the very raison d'être of agencies in the first place) can be combined with an effective system of control and what elements such a system of control should have. ${ }^{44}$ Our (normative) point of departure is that such a system must be one that aligns (i) different concepts and types of controls, (ii) different levels and jurisdictions of control, and (iii) different temporal dimensions of control (ex ante, ongoing, ex post) with the various types of power exercised and with one another, forming a harmonious whole..$^{45}$ Gaps or weaknesses of one form or one level of control (for example, only EU) may to a certain degree perhaps be dealt with by combining it with another form (or forms) of control or at another level or jurisdiction. ${ }^{46}$ To this end, we proceed to address this

43 See M Eliantonio and O Stefan, 'Soft Law Before the European Courts: Discovering a “Common Pattern”?', [2018] 37 Yearbook of European Law, 457-469.

44 Busuioc (2009) (n 24); M Groenleer, 'The European Commission and Agencies', in D Spence (ed.), The European Commission (John Harper Publishing 2006), 156; M Everson, 'Independent Agencies: Hierarchy Beaters?', [1995] 1(2) European Law Journal, 180-204.

45 See in a similar vein M Van Rijsbergen and M Scholten, 'ESMA Inspecting: The Implications for Judicial Control under Shared Enforcement', [2016] 7(3) European Journal of Risk Regulation, 569-579.

46 See F Cacciatore and M Eliantonio, 'Fishing in Troubled Waters? Shared Enforcement of the Common Fisheries Policy and Accountability Gaps', in M Scholten and M Luchtman (eds.), Law Enforcement by EU Authorities (Edward Elgar Publishing 2017), 168-194; see also M Everson, C Monda and E Vos, EU Agencies in between Institutions and Member States (Kluwer Law International 2014). 
question by examining the state of the art of legal and political science scholarship on concepts that could be essential to creating such a system of control and to constructing a design and assessment framework.

How has this volume been designed? First, we have made a preliminary inventory of possible relevant concepts of control based on the state of the art of research in legal scholarship and political science. The chapters in Part I, written by the experts in the relevant concepts, seek to present these findings. These experts have been asked to make their contributions along the lines of the following questions:

1. What does the concept entail, what is its meaning? What is the state of the art of research in legal and political science on this particular concept?

2. What is the function (and place) of the concept in the system of control? How is the concept operationalised in law and in practice? Which institutions are involved and what are the mechanisms and conditions required for the successful operation of the concept in practice?

3. What, if any, are the effects of Europeanisation on this concept as well as on its function and operation within the framework that governs EU agencies?

4. What are the possibilities and limitations of each concept? What challenges does Europeanisation pose for (the operationalisation of) this concept? How may these limitations be remedied through other concepts? What are the effects of the concept for the end-user? ${ }^{47}$

Second, we selected, from the total population of EU agencies, some EU agencies to be included in Part II of this volume as case studies, primarily on the basis of what types of functions they have, ${ }^{48}$ which has implications for the types of decisions they can produce, which in turn relates to the necessity for specific types of controls. ${ }^{49}$ We first made an inventory of all existing EU agencies. We excluded what the Commission calls executive agencies as these work under close supervision by the Commission and are subject to one common Regulation ${ }^{50}$ and legal framework, and as such could be less problematic or prompt different questions from a control perspective in comparison with the so-called regulatory or decentralised EU agencies. ${ }^{51}$ As the functional

\footnotetext{
47 Brenninkmeijer, Mazur, Randma-Liiv and St. Aubyn (n 14).

Craig (n 3).

Chamon (2016) (n 5).

50 Council Regulation (EC) No 58/2003 laying down the statute for executive agencies to be entrusted with certain tasks in the management of Community Programmes.

51 These are the Agency for the Cooperation of Energy Regulators (ACER), Body of European Regulators for Electronic Communications (BEREC), Translation Centre for the Bodies of the European Union (CdT), European Centre for the Development
} 
typology of EU agencies varies greatly among scholars and practitioners, we have tried to include as many possible functions as EU agencies may have: information-gathering, cooperation-providing, service-providing, advisory, regulatory decision-making, direct (vis-à-vis private actors) and indirect (vis-à-vis national authorities) enforcement. We have selected an EU agency to be a case study for each one of these functions and a selected number of specific tasks, powers or outputs that an EU agency may have in this respect. While we do not claim to offer a ' $100 \%$ comprehensive' overview of all possible outputs and decision-making processes, we think that we offer a good sample of possible decision-making procedures, closely interconnecting them with the various types of controls.

The experts contributing to Part II of the book were asked to structure their chapters along the lines of the following questions:

1. What mission, tasks and powers has the agency been entrusted with? What kinds of outputs does the agency produce, and what is their significance in the regulatory process? If necessary, what national counterparts would it be relevant to include?

of Vocational Training (Cedefop), European Agency for Law Enforcement Training (Cepol), Community Plant Variety Office (CPVO), European Aviation Safety Agency (EASA), European Asylum Support Office (EASO), European Banking Authority (EBA), European Centre for Disease Prevention and Control (ECDC), European Chemicals Agency (ECHA), European Defence Agency (EDA), European Environment Agency (EEA), European Fisheries Control Agency (EFCA), European Food Safety Authority (EFSA), European Institute for Gender Equality (EIGE), European Insurance and Occupational Pensions Authority (EIOPA), European Institute of Innovation \& Technology (EIT), European Medicines Agency (EMA), European Monitoring Centre for Drugs and Drug Addiction (EMCDDA), European Maritime Safety Agency (EMSA), European Union Agency for Cybersecurity (ENISA), European Union Agency for Railways (ERA), European Securities and Markets Authority (ESMA), European Training Foundation (ETF), European Union Intellectual Property Office (EUIPO), European Union Institute for Security Studies (EUISS), European Agency for the Operational Management of Large-Scale IT Systems in the Area of Freedom, Security and Justice (EU-LISA), European Agency for Safety and Health at Work (EU-OSHA), European Foundation for the Improvement of Living and Working Conditions (Eurofound), European Union's Judicial Cooperation Unit (Eurojust), European Union Agency for Law Enforcement Cooperation (Europol), European Union Satellite Centre (EU SatCen), European Union Agency for Fundamental Rights (FRA), European Border and Coast Guard Agency (Frontex), European Global Navigation Satellite Systems Agency (GSA), and Single Resolution Board (SRB). There is currently also a proposal for a European Labour Authority. This list may vary in different studies and it is not an intention of this book to go in depth into this debate. 
2. What are all the controlling mechanisms that are in place in the agency's framework in light of the concepts and types of controls discussed in Part I?

3. To what extent is the system of controls comprehensive, that is, to what extent can all agency actions, behaviours and decisions be scrutinised? What could be the challenges from a perspective of ensuring control and what could be the source for those challenges?

4. How can these challenges be addressed, from both a micro-perspective (that is to say, in individual cases), and a macro-perspective (in terms of the relation and interaction between controlling mechanisms, as well as the system of control as a whole)? To what extent can certain challenges in controlling mechanisms be overcome through enhancement or adjustment of other controlling mechanisms? What could be best practice or (sui generis) controlling mechanisms that could be used for other agencies as well?

All contributors have been asked to consider de jure and, to the extent possible and necessary, de facto the state of affairs in the topics that they have investigated. A few rounds of internal peer review have been organised to give feedback on each other's contributions in order to enhance the quality of individual chapters and the coherence of the volume as a whole. Two meetings in Utrecht (5 November 2018 and 12 April 2019) were organised to discuss the ideas, aspirations and aims of this project and the draft chapters.

\section{THIS VOLUME AND ITS CONTRIBUTIONS}

The ambition of this project has been to bring relevant concepts together and to look for useful connections between concepts and types of controls and specific functions and outputs of EU agencies and in some cases their national counterparts. This project has aimed to address the question of how to ensure the controls needed to promote the rule of law in an EU multi-jurisdictional order both conceptually and for specific types of institutions which have been obtaining increasingly far-reaching executive powers, namely EU agencies (and their national counterparts). Our intention has been to contribute to the existing debate on the control over the EU agencies and the EU executive more generally and to boost further (multidisciplinary) research in and help the design of a comprehensive system of controls in a multi-jurisdictional setting of the EU. What concepts and types of controls should and could be connected to build such a comprehensive system? To what extent should and can we connect specific agencies' functions and outputs to a particular set of controls? In this light, could we develop 'control models' based on the type of function of agency and the type of division of competences between the EU and 
national authorities and, in this way, facilitate legislative design and practice of controlling agencies to promote the rule of law? We hope that the contributions in this volume will fuel this debate in academia and by practitioners.

More specifically, for researchers, this volume could be useful for its aim to try to build a multidisciplinary analytical framework by drawing on works of legal and political science scholars. Such a framework can be used to analyse comprehensively controls for specific types of activities of the executive branch institutions, such as EU agencies. To this end, this volume encompasses contributions from a wide variety of scholars from both legal and political science and from experts closely involved in the operation of specific agencies.

For other groups in society, and particularly the EU institutions and agencies, public servants, legislators, legal practitioners, judges and politicians, this book could be useful in offering a broader picture on the question of controls, in particular the design and exercise of such controls. It is logical to expect that EU (and national) agencies should be put under different forms of control depending on which functions/powers they have, which types of decisions they can make, as well as the types of division of competences between EU and national authorities, i.e., hierarchical, parallel and supportive. ${ }^{52}$ The system of controls could perhaps be made with a view to connecting specific tasks, powers and outputs of decision-making processes with specific types of controls. These various types of controls could then be balanced with each other to mitigate each other's 'weak spots', which could also be exacerbated by the multi-jurisdictional setting of the EU. Building a clear framework for controlling EU agencies and EU executive actions and outputs, founded on an underlying logic rather than on the political whims or demands of the day, could serve to reinforce the legitimacy of the EU as a whole. ${ }^{53}$

This volume proceeds as follows. In Part I, Mariavittoria Catanzariti and Alexander Türk start by analysing the effects of Europeanisation on the existing system of controls and mixed administration in light of the ongoing agencification (Chapter 2). Bjorn Kleizen and Koen Verhoest advance the debate on the interrelation between independence, autonomy and control in EU governance by bringing together several academic debates and literature streams (Chapter 3). Gijs Jan Brandsma and Carolyn Moser concentrate on the concept of accountability and the challenges for accountability in the EU setting (Chapter 4). Sacha Prechal and Rob Widdershoven provide an in-depth

52 Scholten, Maggetti and Versluis (n 13).

53 See for an analysis of agency legitimacy, M Maggetti, 'Legitimacy and Accountability of Independent Regulatory Agencies: A Critical Review', [2010] 1 Living Reviews in Democracy 1-19; Chamon (2016) (n 5). 
analysis of the principle of effective judicial protection and the part it plays in relation to composite or mixed administrative procedures of EU agencies (Chapter 5). Paul Craig focuses on the concept of judicial deference and on the extent to which it influences the scope of judicial review in the EU (Chapter 6). Elbert de Jong discusses the concept of liability (tort law) as a possible controlling mechanism in relation to EU agencies (Chapter 7). Frank Meyer analyses the concept of protection of fundamental rights and the challenges that Europeanisation and agencification raise for this concept (Chapter 8). Anoeska Buijze's contribution concludes Part I with a thorough examination of the many facets of the concept of transparency and its potential and limits for controlling EU agencies (Chapter 9).

As a whole, Part I is devoted to analysing relevant concepts with a view to offering the first steps towards building a future comprehensive framework for designing and assessing the mechanisms of control over EU agencies and the executive power in the EU. In this light, we hope to move the debate on further by going beyond a micro level, i.e., identifying, for instance, issues related to one single concept and type of control and offering possible solutions and recommendations for that specific concept, to discussing the issue of control over EU agencies at a higher, meso or even macro level, by connecting different concepts and types of controls, and in relation also to specific agencies' outputs. After all, 'solutions' for one concept may not be suitable when it comes to solving problems related to a different concept, or may even create problems of their own. That is why it is also important to take a 'bird's-eye view' on the issue of controls while maintaining attention on individual concepts.

In Part II, focus is given to a selected number of EU agencies and their specific powers and outputs through the prism of the concepts and types of controls discussed in Part I. We have set the chapters in order in accordance with an increase in the formal powers. However, it should of course be noted that the fact that an agency has less formal or de jure competences does not necessarily mean that questions of control or accountability are less relevant, as agencies' actions may de facto significantly affect the legitimate interests and rights of private parties. At the same time, in light of this book's research questions, the system of controls that govern or should perhaps govern agencies is likely to need to be adjusted and customised to the agencies' specific powers.

Salvatore Nicolosi and David Fernandez-Rojo examine the controls in the case of an 'information-gathering' agency, EASO, with expanding operational powers (Chapter 10). Simone Gabbi, Matthew Wood and Béla Strauss focus their attention on EFSA and assess the challenges to control when an EU agency provides authoritative scientific advice and opinions (Chapter 11). The controls for the inspecting powers of EFCA are discussed by Federica 
Cacciatore and Mariolina Eliantonio (Chapter 12). Tom Huisjes and Stanisław Tosza look into the issue of the controls of a cooperation-type agency, i.e. Eurojust (Chapter 13). Lisette Mustert and Miroslava Scholten's contribution on EASA addresses the issue of controls for shared rule-making and enforcement functions, more specifically the issuing of documents such as technical standards and airworthiness directives (Chapter 14). Controls for the direct and subsidiary enforcement functions of ESMA are investigated by Marloes van Rijsbergen and Marta Simoncini (Chapter 15). Jolien Timmermans and Merijn Chamon concentrate on composite decision-making procedures in the case of the SRB and its procedure of resolution of 'significant banks' (Chapter 16). Finally, in Chapter 17, Miroslava Scholten, Martino Maggetti and Yannis Papadopoulos discuss the findings presented in the earlier chapters and offer comparative insights and observations for researchers and practitioners for the 45 th anniversary of the creation of the first EU agencies and thereafter. 